\title{
Impact of the fermentation broth of Ganoderma lucidum on the quality of Chinese steamed bread
}

\author{
Zhao Guowei ${ }^{1 \dagger}$, Wei Lili2 ${ }^{2 \dagger}$, Liu Yufeng ${ }^{1}$ and Wang Hailei ${ }^{{ }^{*}}$
}

\begin{abstract}
The potential of fermentation broth of Ganoderma lucidum $\left(\mathrm{FB}_{\mathrm{G}}\right)$ in improving the quality of Chinese steamed bread (CSB) was firstly evaluated. The sensory quality scores of CSB treated by FB $\mathrm{B}_{\mathrm{G}}$ are significantly higher than that of CSB in the control, and texture profile analysis also indicates the increase of CSB hardness and chewiness caused by $\mathrm{FB}_{\mathrm{G}}$. Observation on micro-structure of CSB shows that formation of larger pores and expansion of starch granules are the important reasons for the improvement of CSB specific volume ( vol $_{s}$ ), and granule expansion is due to that gluten network distributed in CSB is destroyed as a result of cross-linkage of flour proteins catalyzed by laccase, which makes starch granules releasing from the network easily contact with steam or other enzymes during the proofing and steaming of dough. Moreover, $\mathrm{FB}_{\mathrm{G}}$ contains amylases which not only convert amylopectin to amylose, but also degrade starch to glucose, maltose and polysaccharides, correspondingly resulting in changes of amylose/amylopectin (Ae/An) ratio of flour and CSB vol $I_{S}$ and the latter is because more $\mathrm{CO}_{2}$ produced by the yeast during CSB making leads to the larger pore area in crumb. Both hardness and chewiness are determined by the comprehensive effect of protein cross-linkage, Ae/An ratio and $\mathrm{vol}_{S}$ change, and this viewpoint gives a logical explanation for the effects of $0.025-0.10 \mathrm{ml} / \mathrm{g}$ of $\mathrm{FB}_{\mathrm{G}}$ on hardness and chewiness of CSB.
\end{abstract}

Keywords: Laccase, Amylose, Amylase, Chinese steamed bread, Ganoderma lucidum, Amylopectin

\section{Introduction}

Chinese steamed bread (CSB) is a fermented wheat flour product. Its preparation process is similar to that of western-style pan bread, but the final product is steamed in a steamer, not baked in an oven. Steaming process has an advantage over baking since it uses water vapor temperature which is much lower than baking temperature (around $180-220^{\circ} \mathrm{C}$ ). Therefore, nutrients might be better retained when compared to the baked bread (Victoria et al. 2013). Over the centuries, within the intercommunication of food culture among different countries, CSB has spread from China to other Asian, North America and European countries (Wu et al. 2012). In CSB making process, although protein and starch, as the main

\footnotetext{
*Correspondence: whl@htu.cn

${ }^{\dagger}$ Zhao Guowei and Wei Lili contributed equally to the article

${ }^{1}$ College of Life Sciences, Henan Normal University, Xinxiang 453007,

China

Full list of author information is available at the end of the article
}

components in flour, were the most important factors in determining CSB quality, lipids, non-starch polysaccharides and especially some enzymes also played a comparatively important role (Oliveira et al. 2014; Singh et al. 2010). The effects of several enzymes including laccase, xylanase and tyrosinase on the properties of oat and wheat dough were investigated extensively (Flander et al. 2011; Selinheimo et al. 2006; Su et al. 2005), but, the higher cost of these purified enzymes becomes a bottleneck impeding their commercial application in view of the low added value of CSB as a daily consumer goods.

Ganoderma lucidum is a medicinal mushroom that has been used as a home remedy for the general promotion of health and longevity in East Asia, and it is popularly used worldwide in the form of dietary supplements (Stanley et al. 2005). The information indicates that G. lucidum could be potentially acceptable for food applications. The fermentation broth of G. lucidum $\left(\mathrm{FB}_{\mathrm{G}}\right)$ obtained by submerged cultivation is a traditional Chinese medicine 
which is used to treat chronic tracheitis and hypercholesterolemia in China, and it contains many useful second metabolites including a series of enzymes, polysaccharides and triterpenoids that are considered to possess multiple biological activities (Li et al. 2011; Xu et al. 2010; Zhou et al. 2014).

Taking these considerations into account, $\mathrm{FB}_{\mathrm{G}}$ was prepared and added to wheat flour as a relatively inexpensive food additive. The aims of this study are (i) to investigate potential of $\mathrm{FB}_{\mathrm{G}}$ in improving $\mathrm{CSB}$ quality, and (ii) to study impact of $\mathrm{FB}_{\mathrm{G}}$ on $\mathrm{CSB}$ properties and elucidate its function during CSB making. To the best of our knowledge, there is little information available in the previous literature about application of $\mathrm{FB}_{\mathrm{G}}$ to $\mathrm{CSB}$ making.

\section{Materials and methods}

\section{Chemicals, raw materials and strains}

The standard samples of amylopectin and amylose, guaiacol and 2, 2-azino-bis (3-ethylbenzthiazoline-6-sulfonic acid) diammonium salt (ABTS) were obtained from Sigma. Wheat flour containing $70.7 \%$ of starch, $12.1 \%$ of moisture, $10.4 \%$ of protein and $0.53 \%$ of ash was supplied by Zhengzhou Jingyuan Flour Co., Ltd., China. The dehydrated yeast (Saccharomyces cerevisiae) bought from Angel Yeast Co., Ltd., China, was a kind of commercial instant yeast for common production of CSB. G. lucidum (CGMCC 5.533) was obtained from China General Microbiological Culture Collection Center, Beijing, China, and the fungus was maintained on potato dextrose agar (PDA) slant at $4{ }^{\circ} \mathrm{C}$ and sub-cultured every 3 months.

\section{Preparation of the $\mathrm{FB}_{\mathbf{G}}$}

Ganoderma lucidum was grown on PDA for $3 \mathrm{~d}$ at $28^{\circ} \mathrm{C}$, and mycelial suspension was prepared using the sterile water. During the submerged cultivation, the Erlenmeyer flasks $(500 \mathrm{ml})$ containing $100 \mathrm{ml}$ of liquid medium were inoculated with $5 \mathrm{ml}$ of mycelial suspension, and incubated in a thermostat shaker at $28{ }^{\circ} \mathrm{C}$ and $180 \mathrm{rpm}$. The liquid medium was composed of $40 \mathrm{~g} / \mathrm{l}$ glucose, $20 \mathrm{~g} / \mathrm{l}$ wheat bran, $10 \mathrm{~g} / \mathrm{l}$ peptone, $3.0 \mathrm{~g} / 1 \mathrm{KH}_{2} \mathrm{PO}_{4}$ and $1.5 \mathrm{~g} / \mathrm{l}$ $\mathrm{MgSO}_{4} \cdot 7 \mathrm{H}_{2} \mathrm{O}$. After 7-day cultivation, the medium was centrifuged at $5000 \mathrm{rpm}$ for $10 \mathrm{~min}$ and the supernatant was defined as $\mathrm{FB}_{\mathrm{G}}$.

\section{Zymogram analysis of laccase}

During the submerged cultivation, laccase activity was determined with ABTS as a substrate (Zilly et al. 2012). After the cultivation, zymogram of laccase in $\mathrm{FB}_{\mathrm{G}}$ was analyzed by native polyacrylamide gel electrophoresis (native-PAGE) which was performed under nondenaturing conditions. The separating and stacking gels contained 12 and 5\% concentrations of acrylamide, respectively. The buffer solutions were $50 \mathrm{mM}$ Tris $-\mathrm{HCl}$ ( $\mathrm{pH}$ 9.5) for the separating gel and $18 \mathrm{mM}$ Tris- $\mathrm{HCl}(\mathrm{pH}$ 7.5) for the stacking gel. The electrode reservoir solution was $25 \mathrm{mM}$ Tris and $190 \mathrm{mM}$ glycine ( $\mathrm{pH}$ 8.4). After electrophoresis, visualization of protein bands was achieved by Coomassie brilliant blue (R350, Pharmacia) staining. Activity staining of laccase was performed by incubating the PAGE gel in $0.5 \mathrm{mM}$ sodium acetate buffer $(\mathrm{pH} 5.5)$ containing $0.02 \%$ guaiacol at $25 \pm 1{ }^{\circ} \mathrm{C}$.

\section{Making process and quality test of CSB}

The making process of CSB is as follows: in the treatment group, $\mathrm{FB}_{\mathrm{G}}$ was added to flour at the levels of 0.025 , 0.05 and $0.10 \mathrm{ml} / \mathrm{g}$, respectively; in the control group, no $\mathrm{FB}_{\mathrm{G}}$ was added. The formulation of CSB is: wheat flour $100.0 \mathrm{~g}$, dehydrated yeast $1.0 \mathrm{~g}$ and distilled water $(50 \mathrm{ml})$. The mixture of flour and yeast was kneaded to form dough, and the dough was sheeted for 20 times and divided into several pieces. The piece doughs were rounded, molded manually and proofed for $50 \mathrm{~min}$ at $38{ }^{\circ} \mathrm{C}$ and $85 \%$ relative humidity. The proofed doughs were steamed for $20 \mathrm{~min}$ in a steamer.

The quality of CSB was evaluated according to the evaluation criteria of CSB (SB/T10139-93, Ministry of Internal Trade, China). Volume was measured by rapeseed displacement method (Pyler 1988) after the cooling. The pore in crumb was photographed and observed after slicing from the middle using a blade (Leica 818, Germany). Sensory evaluation was judged by thirty experts according to the 100-point evaluation scheme described in Table 1 (Lin et al. 2012).

\section{Texture profile analysis (TPA)}

TPA was determined by a TA-XT2i texture analyser (Stable Micro Systems, Ltd., Godalming, UK) according to the method described by Kadan et al. (2001). CSB was sliced horizontally and a piece, $20 \mathrm{~mm}$ height, was compressed to $30 \%$ of its height. The test conditions were as follows: pre-test speed $3 \mathrm{~mm} / \mathrm{s}$, test speed $1 \mathrm{~mm} / \mathrm{s}$, posttest speed $5 \mathrm{~mm} / \mathrm{s}$ and trigger force $5 \mathrm{~g}$. The parameters including hardness, springiness, chewiness and resilience were evaluated based on the data of TPA.

\section{Micro-structure observation}

The CSB cubes (each side of the cube $=0.5 \mathrm{~cm}$ ) prepared as described by Selinheimo et al. (2007) were cut into sections with the thickness of $15 \mu \mathrm{m}$ by a Leica HM355 rotary microtome (Germany), and then transferred onto glass slides. The sections were stained with Light green solution $(0.1 \%)$ and Lugol's iodine solution $\left(\mathrm{I}_{2}, 0.33 \%\right.$, $\mathrm{w} / \mathrm{v} ; \mathrm{KI}, 0.67 \%, \mathrm{w} / \mathrm{v})$ to dye starch to dark or brown and protein to green, respectively. The stained samples were washed with distilled water for $1 \mathrm{~min}$, and then observed 
Table 1 Sensory evaluation criteria and scores of CSBs treated by $\mathrm{FB}_{\mathrm{G}}$ with the different dosages

\begin{tabular}{|c|c|c|c|c|c|c|}
\hline \multirow[t]{2}{*}{ CSB attributes } & \multirow{2}{*}{$\begin{array}{l}\text { Max. } \\
\text { score }\end{array}$} & \multirow[t]{2}{*}{ Evaluation criteria } & \multicolumn{4}{|c|}{$\mathrm{FB}_{\mathrm{G}}$ dosage $(\mathrm{ml} / \mathrm{g})$} \\
\hline & & & 0 & 0.025 & 0.05 & 0.10 \\
\hline Specific volume (SV) & 20 & 20-(2.3-SV)/0.1 & $17.1 \pm 0.2$ & $18.1 \pm 0.1$ & $18.9 \pm 0.2$ & $19.2 \pm 0.2$ \\
\hline External & 15 & $\begin{array}{l}\text { Good symmetry, smooth skin: 12.1-15.0; medium: 9.1-12.0; } \\
\text { bad symmetry, coarse skin: 1.0-9.0 }\end{array}$ & $12.0 \pm 0.08$ & $13.0 \pm 0.09$ & $13.0 \pm 0.07$ & $13.0 \pm 0.05$ \\
\hline Crumb's structure & 15 & $\begin{array}{l}\text { Regular and small crumb's pore size: } 12.1-15.0 ; \text { medium: } \\
\text { 9.1-12.0; irregular and large crumb's pore size: 1.0-9.0 }\end{array}$ & $8.0 \pm 0.07$ & $14.0 \pm 0.10$ & $7.0 \pm 0.06$ & $7.1 \pm 0.10$ \\
\hline $\begin{array}{l}\text { Recovery after } \\
\text { compression }\end{array}$ & 20 & $\begin{array}{l}\text { Good recovery, firm bite: } 16.1-20.0 ; \text { medium: 12.1-16.0; } \\
\text { bad recovery, soft bite: 1.0-12.0 }\end{array}$ & $13.9 \pm 0.10$ & $14.5 \pm 0.10$ & $17.0 \pm 0.20$ & $14.0 \pm 0.30$ \\
\hline Stickiness & 15 & Chewier: 12.1-15.0; medium: 9.1-12.0; sticky: 1.0-9.0 & $10.0 \pm 0.21$ & $11.6 \pm 0.10$ & $12.5 \pm 0.20$ & $11.0 \pm 0.25$ \\
\hline Color & 10 & White, milky: 8.1-10.0; medium: 6.1-8.0; dark: 1.0-6.0 & $8.7 \pm 0.10$ & $8.1 \pm 0.06$ & $7.9 \pm 0.10$ & $7.5 \pm 0.07$ \\
\hline Flavor and smell & 5 & $\begin{array}{l}\text { Natural wheat flavor, no bad odour: 4.1-5.0; medium: } \\
\text { 3.1-4.0; bad odour: 1.0-3.0 }\end{array}$ & $4.1 \pm 0.04$ & $4.9 \pm 0.05$ & $4.8 \pm 0.05$ & $4.9 \pm 0.06$ \\
\hline Total score & 100 & & $73.3 \pm 0.51$ & $90.1 \pm 0.5$ & $078.1 \pm 0.42$ & $80.1 \pm 0.37$ \\
\hline
\end{tabular}

under a microscope with an image analysis system (Image-Pro Plus, V4.0, Media Cybernetics).

\section{Protein cross-linkage catalyzed by laccase}

Laccase in $\mathrm{FB}_{\mathrm{G}}$ was purified by two $\left(\mathrm{NH}_{4}\right)_{2} \mathrm{SO}_{4}$ precipitation steps: (i) $40 \%$ saturated $\left(\mathrm{NH}_{4}\right)_{2} \mathrm{SO}_{4}$ solution was used to remove other proteins; and (ii) $70 \%$ saturated $\left(\mathrm{NH}_{4}\right)_{2} \mathrm{SO}_{4}$ solution was used to precipitate laccase. The resulting precipitate was dialyzed to remove $\left(\mathrm{NH}_{4}\right)_{2} \mathrm{SO}_{4}$, and the desalted enzyme solution was applied to a DEAE52 column pre-equilibrated with sodium phosphate buffer ( $\mathrm{pH}$ 7.2). The absorbed laccase was eluted using $0.2 \mathrm{M} \mathrm{NaCl}$, and the active fractions were collected, dialyzed, and concentrated by lyophilization.

Protein cross-linkage assay was conducted according to the following steps (Gao et al. 2010): after addition of the purified laccase $(0.5$ and $2.0 \mathrm{ml} / \mathrm{g}$, respectively), the flour was kneaded into dough, and proofed for $50 \mathrm{~min}$ at $38{ }^{\circ} \mathrm{C}$. Starch in the dough was removed by washing using the sterile water, and fat was extracted twice with $100 \mathrm{ml}$ acetone. The proteins left were dissolved in $0.1 \mathrm{M}$ sodium phosphate buffer ( $\mathrm{pH}$ 6.5), and the protein solution $(1.5 \mathrm{mg} / \mathrm{l})$ was analyzed by sodium dodecyl sulfate polyacrylamide gel electrophoresis (SDS-PAGE).

\section{Starch degradation catalyzed by $\mathrm{FB}_{\mathrm{G}}$}

Two tests were conducted to study the impact of $\mathrm{FB}_{\mathrm{G}}$ on starch. In test $1, \mathrm{FB}_{\mathrm{G}}(0.0250 .05$ and $0.10 \mathrm{ml} / \mathrm{g})$ was added to three tubes each containing $30 \mathrm{ml}$ of amylopectin solution $(60 \mathrm{mg} / \mathrm{l})$. After $3 \mathrm{~h}$ reaction at $25{ }^{\circ} \mathrm{C}$ and $\mathrm{pH} 5.5$, color change of solution was recorded and contents of both amylopectin and amylose were determined by the method of Adejumo et al. (2013). In test 2, $\mathrm{FB}_{\mathrm{G}}(0.10 \mathrm{ml} / \mathrm{g})$ was added to amylopectin $(0.67 \mathrm{~g} / \mathrm{ml})$ and amylose $(0.83 \mathrm{~g} / \mathrm{ml})$ suspension, respectively. After
$3 \mathrm{~h}$ reaction at $25^{\circ} \mathrm{C}$ and $\mathrm{pH} 5.5$, the supernatants were analyzed by silica gel thin layer chromatograph (TLC) using n-butanol: ethyl acetate: pyridine: water (6:1:5:4) as mobile phase. Both glucose and maltose were measured by the high-performance liquid chromatography (HPLC) with refractive index detection (Liu et al. 2006).

\section{Effect of glucose and maltose on CSB characteristics}

Four treatments (T1-T4) were designed. In T1, no glucose and maltose was added to flour; in T2-T4, both glucose and maltose $(24.2 \mathrm{mg} / \mathrm{g}$ glucose $+1.7 \mathrm{mg} / \mathrm{l}$ maltose; $47.4 \mathrm{mg} / \mathrm{g}$ glucose $+3.0 \mathrm{mg} / \mathrm{l}$ maltose; $69.9 \mathrm{mg} / \mathrm{g}$ glucose $+4.1 \mathrm{mg} / \mathrm{l}$ maltose) were added to flour, respectively. All of the flours were used to make CSBs, and the CSBs obtained were sliced from the middle. The pore number and total pore area in CSB slices were analyzed quantitatively by digital image analysis (Sapirstein et al. 1994; Zghal et al. 2001) using the software of Matlab 7.0 (Mathworks, Natick, MA, USA).

\section{Statistical methods}

The obtained data in this work were presented as mean \pm standard deviation of multiple measurements, and the statistical analysis of data was carried out using the software SPSS 12.0 for Windows. One-way ANOVA was used to analyze the data to ascertain whether the change of Ae/An ratio significantly affected CSB properties. The level of significance of correlation coefficient was analyzed by a two-tailed test.

\section{Results}

Submerged cultivation and zymogram analysis of laccase The G. lucidum used in this work is a good laccase producer (Wang et al. 2013), and thus laccase activity was 


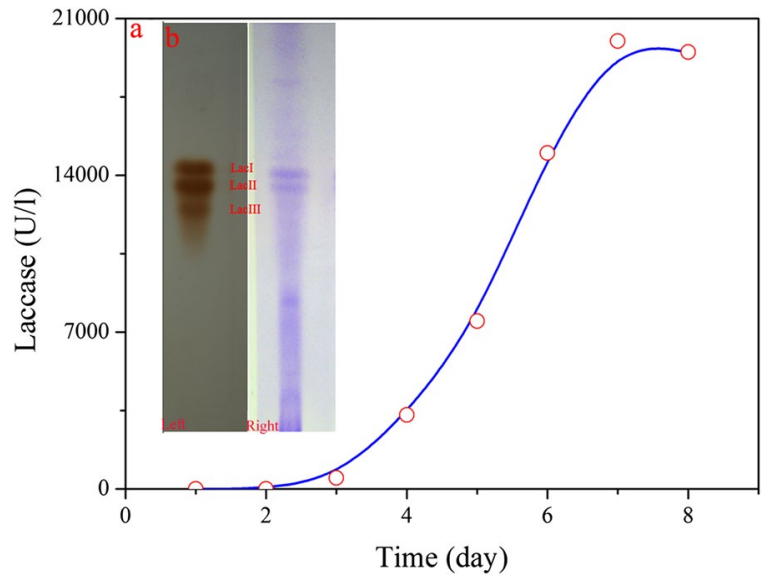

Fig. 1 Laccase activity measurement and isoenzyme analysis. a Laccase activity varied with time during the submerged fermentation; b native-PAGE analysis of laccase isoenzymes: left, guaiacol staining; right, Coomassie brilliant blue staining

measured during the submerged cultivation. Laccase appeared in $\mathrm{FB}_{\mathrm{G}}$ on day 2, and then its activity increased with time. On day 7 , a maximum laccase activity, 18,000 $\mathrm{U} / \mathrm{l}$, was obtained at $500 \mathrm{ml}$ shake-flask level (Fig. 1a). The $\mathrm{FB}_{\mathrm{G}}$ obtained was analyzed by native-PAGE, and three clear and distinct bands were observed after incubating the gel with the laccase substrate, guaiacol (Fig. 1b-left), which indicates the presence of three laccase isoforms (Lac I-III) in $\mathrm{FB}_{\mathrm{G}}$ (Ko et al. 2001). NativePAGE gel stained with Coomassie brilliant blue shows that both Lac I and Lac II are the main laccase isoforms, and they are much higher than Lac III in protein content (Fig. 1b-right).

\section{Sensory evaluation}

CSB quality assessment is largely based on personal judgment and subjective qualitative evaluation, and the results reflect the consumer preferences (Shah et al. 2006). Sensory evaluation analysis clearly demonstrates that $\mathrm{FB}_{\mathrm{G}}$ has a positive effect on CSB quality. It remarkably modifies organoleptic properties of CSB including the specific volume $\left(\mathrm{vol}_{S}\right)$, external, crumb's structure, recovery after compression, stickiness, color, flavor and smell. Compared with the control, appearance of $\mathrm{FB}_{\mathrm{G}}$ in flour $(0.025-0.10 \mathrm{ml} / \mathrm{g})$ improved the sensory evaluation score of CSB. CSB supplementing $0.025 \mathrm{ml} / \mathrm{g}$ of $\mathrm{FB}_{\mathrm{G}}$ fetched the highest total score (Table 1), and it was significantly superior over the other CSBs with respect to attributes except color. Color of all of the treated CSBs became a little darker with the increase of $\mathrm{FB}_{\mathrm{G}}$ dosage due to the fact that laccase catalyzes amino acids or phenolic acids such as ferulic acid in flour to produce some color substances (Selinheimo et al. 2007).

\section{Specific volume}

Volume is the most important quality parameter for CSB. $\mathrm{Vol}_{\mathrm{S}}$ of the treated CSBs increased with the $\mathrm{FB}_{\mathrm{G}}$ dosage, and all of them are larger than that of the control. Thus, it is feasible to increase CSB volume by $\mathrm{FB}_{\mathrm{G}}$. Photographs of CSB slices (Fig. 2) show that the pore size in $\mathrm{CSB}$ treated with $0.025 \mathrm{ml} / \mathrm{g}$ of $\mathrm{FB}_{\mathrm{G}}$ was noticeable regular when compared to that of the control. The higher $\mathrm{FB}_{\mathrm{G}}$ dosage ( $\geq 0.05 \mathrm{ml} / \mathrm{g}$ ) changed pore size in CSB to more irregular and larger, and this phenomenon can explain the scores in crumb's structure of CSBs in sensory evaluation. Obviously, formation of the large pore is also an important reason for the larger $\mathrm{vol}_{S}$ of CSBs treated with $\mathrm{FB}_{\mathrm{G}}$.

\section{Effect of $\mathrm{FB}_{\mathrm{G}}$ on size distribution of starch granules}

A more interesting phenomenon was found by observing CSB micro-structure: the size of starch granules changes with the $\mathrm{FB}_{\mathrm{G}}$ dosage. Compared with the treatment group, number of the small starch granules $\left(<200 \mu \mathrm{m}^{2}\right)$ in the control group decreased, while number of the larger starch granules $\left(>200 \mu \mathrm{m}^{2}\right)$ significantly increased (Fig. 3). In view of the stable amount of total starch granules, the expansion of starch granule will also lead to the larger $\mathrm{vol}_{S}$ of CSB. Thus, we can also explain enlargement

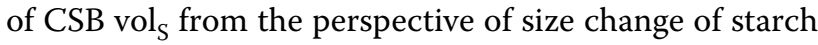
granules.

Considering that CSBs in both the control and treatment group were performed the same processing except the $\mathrm{FB}_{\mathrm{G}}$ dosage, the appearance of larger starch granules should be attributed to the addition of $\mathrm{FB}_{\mathrm{G}}$. Therefore, the effect of $\mathrm{FB}_{\mathrm{G}}$ on flour proteins was studied. After the staining, the yellow or dark starch granules in the control were entrapped in the network of gluten protein (Fig. 4a). However, the appearance of $0.025 \mathrm{ml} / \mathrm{g}$ of $\mathrm{FB}_{\mathrm{G}}$ led to a clear cross-linkage of proteins (Fig. 4b). When $\mathrm{FB}_{\mathrm{G}}$ was increased to 0.05 and $0.10 \mathrm{ml} / \mathrm{g}$, the large protein-rich areas were formed (Fig. 4c, d), and the uniform protein network suffered serious devastation.

Laccase activity in $\mathrm{FB}_{\mathrm{G}}$ was approximately $20 \mathrm{U} / \mathrm{ml}$, and the fungal laccases are able to cross-link proteins (Ercili et al. 2009; Figueroa-Espinoza and Rouau 1998; FigueroaEspinoza et al. 1999). Thus, laccase in $\mathrm{FB}_{\mathrm{G}}$ was purified by $\left(\mathrm{NH}_{4}\right)_{2} \mathrm{SO}_{4}$ precipitation and DEAE52 column chromatography. After the two-step purification, the specific activity of laccase was increased from 1.66 to $17.60 \mathrm{U} / \mathrm{mg}$ (Table 2). The enzyme was purified to 10.6 fold, and the recovery rate was $38 \%$.

Ability of the purification laccase to cross-link proteins was determined. Figure 5 clearly shows that 0.5 and $2.0 \mathrm{U} / \mathrm{g}$ of laccase can cross-link flour proteins by SDSPAGE analysis. Compared with the reference, the content of protein $\left(A_{1}\right)$ with the higher molecular weight was 

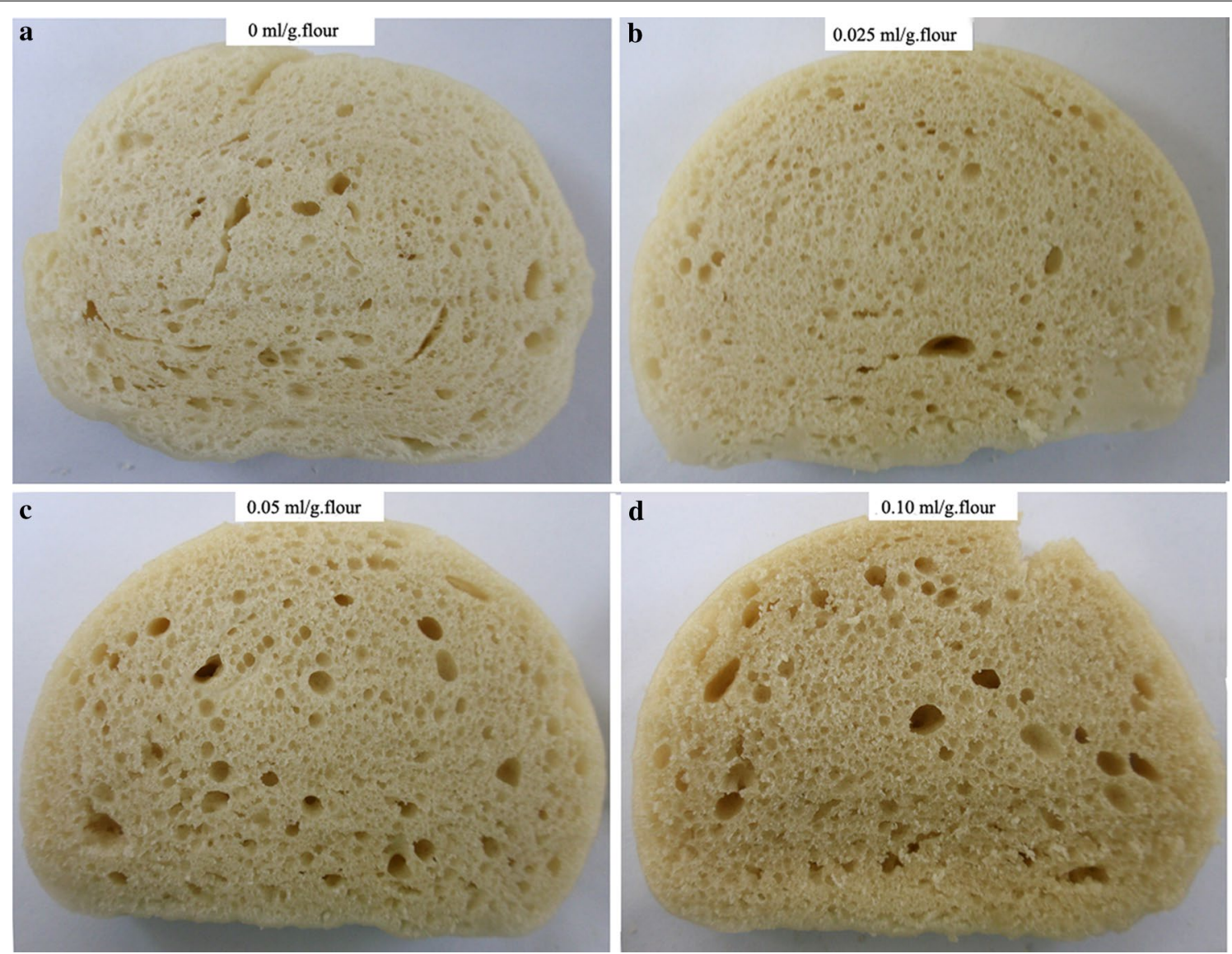

Fig. 2 Visual examination of the effect of $\mathrm{FB}_{\mathrm{G}}$ on pore size of the crumbs. a The reference; $\mathbf{b} 0.025 \mathrm{ml} / \mathrm{g} ; \mathbf{c} 0.05 \mathrm{ml} / \mathrm{g} ; \mathbf{d} 0.10 \mathrm{ml} / \mathrm{g}$

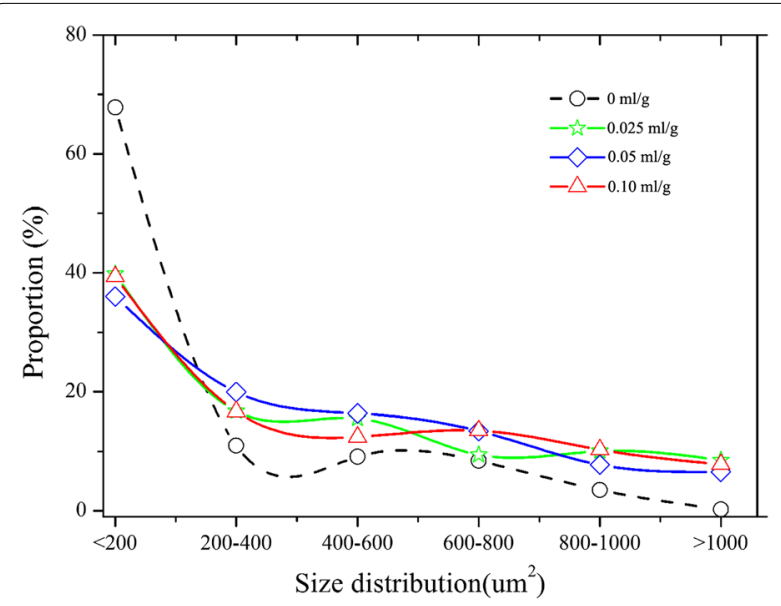

Fig. 3 Size distribution of starch granules in CSBS

increased, and also some new proteins $\left(A_{2-} A_{4}\right)$ appeared in the gel (Fig. 5, lanes 1-2). In addition, a lower molecular weight protein $\left(A_{5}\right)$ presenting in lane 3 disappeared in lanes $1-2$. A probable explanation is that the protein was used to form the higher molecular weight products by cross-linking with other substances. Thus, the devastation of uniform protein network in CSB might be attributed to cross-linkage of proteins catalyzed by laccase (Flander et al. 2008; Labat et al. 2000).

\section{TPA of CSB}

As shown in Table $1, \mathrm{FB}_{\mathrm{G}}$ at the dosages of $0.025-$ $0.10 \mathrm{ml} / \mathrm{g}$ gives CSB a better score in recovery after compression and stickiness in sensory evaluation. Since the scores of recovery after compression and stickiness correspond to hardness and chewiness of CSB in TPA, respectively. Thus, TPA was conducted to validate the reliability of sensory evaluation. As shown in Fig. 6, the addition of $0.025-0.10 \mathrm{ml} / \mathrm{g}$ of $\mathrm{FB}_{\mathrm{G}}$ in flour increased CSB hardness, and the maximum hardness, 2014, was obtained at $0.05 \mathrm{ml} / \mathrm{g}$ of $\mathrm{FB}_{\mathrm{G}}$. However, the hardness decreased at the $\mathrm{FB}_{\mathrm{G}}$ dosage of $0.10 \mathrm{ml} / \mathrm{g}$. The same tendency in chewiness was observed. In addition, $\mathrm{FB}_{\mathrm{G}}$ had no significant influence on resilience and springiness of CSB. Hence, the sensory evaluation of CSB attributes is supported by TPA data. 

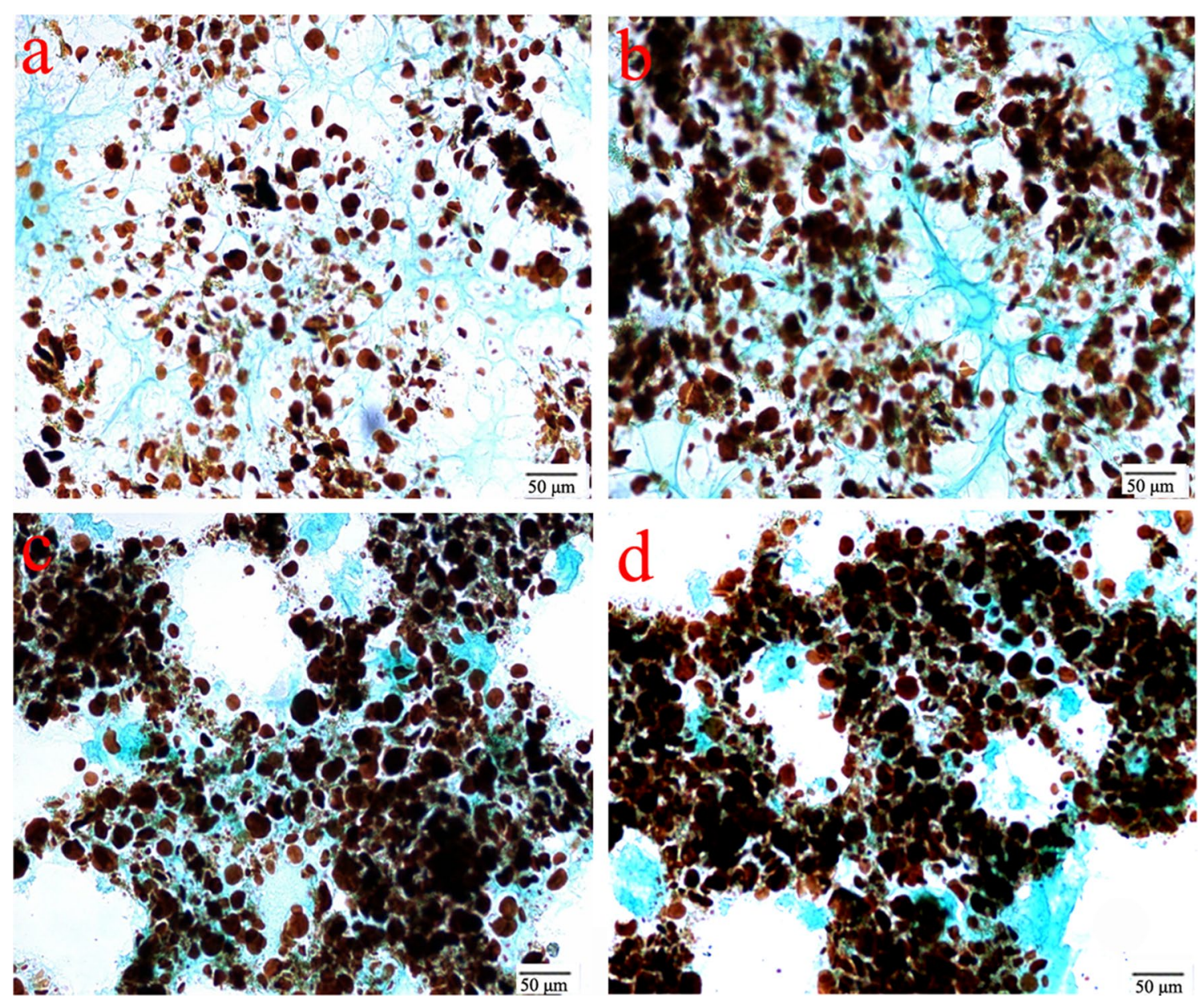

Fig. 4 Microscopy examination of the effect of $\mathrm{FB}_{\mathrm{G}}$ on proteins and starch granules in the crumbs. a The reference; b $0.025 \mathrm{ml} / \mathrm{g} ; \mathbf{c} 0.05 \mathrm{ml} / \mathrm{g} ; \mathbf{d}$ $0.10 \mathrm{ml} / \mathrm{g}$

Table 2 Summary of laccase purification

\begin{tabular}{lllcccc}
\hline Purification & Volume $(\mathbf{m l})$ & $\begin{array}{l}\text { Laccase } \\
\text { activity }(\mathbf{U})\end{array}$ & Protein $(\mathbf{m g})$ & $\begin{array}{l}\text { Specific activity } \\
(\mathbf{U} / \mathbf{m g})\end{array}$ & $\begin{array}{l}\text { Purification } \\
\text { multiple }\end{array}$ & $\begin{array}{l}\text { Recovery } \\
\text { rate (\%) }\end{array}$ \\
\hline $\mathrm{FB}_{\mathrm{G}}$ & 10 & 501 & 302.7 & 1.66 & 1.00 & 100 \\
$\left(\mathrm{NH}_{4}\right)_{2} \mathrm{SO}_{4}$ precipitation & - & 395 & 103.2 & 3.80 & 2.31 & 79 \\
DEAE52 column chromatography & 8 & 190 & 10.8 & 17.6 & 4.60 & 38 \\
\hline
\end{tabular}

\section{Discussion}

Effect of cross-linkage of protein on CSB characteristics

The facts above mentioned demonstrate that $0.025-$ $0.10 \mathrm{ml} / \mathrm{g}$ of $\mathrm{FB}_{\mathrm{G}}$ had a significant influence on CSB hardness and chewiness. The previous literature has proven that laccase is able to improve CSB hardness by crosslinking proteinaceous food matrices (Selinheimo et al. 2006; Minussi et al. 2002), and in this work, both microstructure observation and SDS-PAGE analysis show the ability of laccase in $\mathrm{FB}_{\mathrm{G}}$ to cross-link flour proteins. Thus, cross-linkage of protein catalyzed by laccase is one of the important reasons for improvement of CSB hardness and chewiness. In addition, the cross-linkage of protein also can explain formation of the larger starch granules during CSB making: the cross-linkage causes the destruction of gluten network, which results in the release of small starch granules embedded in the network. The small granules easily contact with steam or enzymes during the 


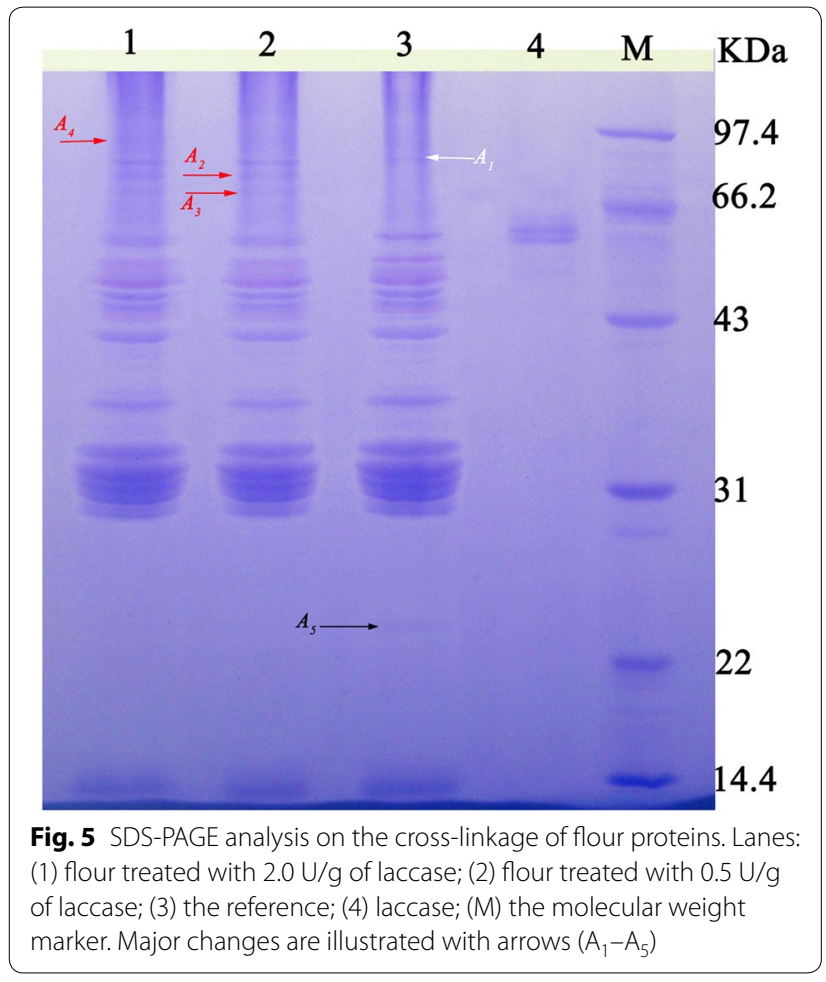

proofing and steaming of dough, leading to the granule expansion such as the expansion of amylopectin accounting approximately for $65-81 \%$ of starch (Nakamura 2002), and then formation of the larger starch granules. Nutritionally, the small starch granules embedded in the protein network are dense, and uneasy to be hydrolyzed, while the larger starch granules are suitable to be digested because of their loose structure.

\section{Effect of amylopectin conversion on CSB characteristics}

The main component of flour, starch, plays an important role in determining CSB quality. Therefore, the effect of $\mathrm{FB}_{\mathrm{G}}$ on starch was studied. Amylopectin and amylose are the main components of starch in wheat flour (Zou et al. 2012), and they are stained purple or amaranth and brown or blue by $\mathrm{I}_{2}$, respectively. In test 1 , after addition of $\mathrm{FB}_{\mathrm{G}}$ to the tubes, the solutions became browner with the increase of $\mathrm{FB}_{\mathrm{G}}$ dosage, which indicates the production of amylose (Fig. 7). The measurement data (Fig. 7-E1) also prove the appearance of amylose in the reaction system. Accompanying with the decrease of amylopectin, 1.55, 2.58 and $3.56 \mathrm{mg} / \mathrm{l}$ of amylose appeared in the tubes added $0.025,0.05$ and $0.10 \mathrm{ml} / \mathrm{g}$ of $\mathrm{FB}_{\mathrm{G}}$, respectively. Therefore, $\mathrm{FB}_{\mathrm{G}}$ should contain isoamylase which is able to convert amylopectin to amylose by breaking a-1, 6-glucosidic bond (Kudanga et al. 2011; Zhu et al. 2013). To the best of our knowledge, this is the first report about the appearance of isoamylase during submerged cultivation of G. lucidum.

During CSB making, the conversion from amylopectin to amylose means the change of amylose/amylopectin $(\mathrm{Ae} / \mathrm{An})$ ratio of flour. Figure 8a demonstrates that $0.025-0.10 \mathrm{ml} / \mathrm{g}$ of $\mathrm{FB}_{\mathrm{G}}$ increases $\mathrm{Ae} / \mathrm{An}$ ratio. Ae/An ratio of flour was adjusted by the commercial amylopectin and amylose in order to investigate its effect on CSB characteristics, and after the adjustment, the flour with the different Ae/An ratio was used to make CSB. The results show that Ae/An ratio is positively correlative with hardness and chewiness of CSB (Table 3). Two-tailed test indicates that correlation coefficients are 0.972 and 0.963 , respectively, and correlations are significant at the 0.01 level. Thus, the enhancement of $\mathrm{Ae} / \mathrm{An}$ ratio of flour induced by $0.025-0.10 \mathrm{ml} / \mathrm{g}$ of $\mathrm{FB}_{\mathrm{G}}$ also contributes to improvement of hardness and chewiness of CSB.

\section{Starch degradation}

Now, both protein cross-linkage and change of Ae/ An ratio catalyze by $\mathrm{FB}_{\mathrm{G}}$ can be used to explain the improvement of hardness and chewiness of CSB. However, neither of them can explain why both hardness and chewiness decreased at the $\mathrm{FB}_{\mathrm{G}}$ dosage of $0.10 \mathrm{ml} / \mathrm{g}$. In Fig. 7-E1, it should be noted that only $5.9 \%$ amylopectin was converted to amylose when amylopectin solution was treated by $0.10 \mathrm{ml} / \mathrm{g}$ of $\mathrm{FB}_{\mathrm{G}}$, and the other products include glucose, maltose and polysaccharides also were produced during the reaction (Fig. 7-E2). In addition, amylose is degraded by $\mathrm{FB}_{\mathrm{G}}$ too. When amylose was treated by $0.10 \mathrm{ml} / \mathrm{g}$ of $\mathrm{FB}_{\mathrm{G}}$ for $3 \mathrm{~h}$, the products in supernatant include glucose, maltose and other soluble polysaccharides by TLC analysis. These evidences show that the enzymes in $\mathrm{FB}_{\mathrm{G}}$ also act on a-1, 4-glucosidic bonds of amylopectin and amylose. Based on the analysis of degradation products of starch, the $\mathrm{FB}_{\mathrm{G}}$ used at least has a-amylase activity, and this result accords with our previous report (Li et al. 2011).

\section{Effect of glucose and maltose on CSB characteristics}

The facts above mentioned prove that the appearance of $\mathrm{FB}_{\mathrm{G}}$ in flour leads to degradation of a small amount of starch. Figure $8 \mathrm{~b}$ shows that approximately 24.2, 47.4 and $69.9 \mathrm{mg} / \mathrm{g}$ of glucose as well as $1.7,3.0$ and $4.1 \mathrm{mg} / \mathrm{g}$ of maltose were correspondingly produced when $0.025-$ $0.10 \mathrm{ml} / \mathrm{g}$ of $\mathrm{FB}_{\mathrm{G}}$ was added to flour. Analysis on the effect of glucose and maltose on CSB characteristics shows that CSB slice in T2 obtained the maximum pore number. However, the total pore area in T4 was the largest in the

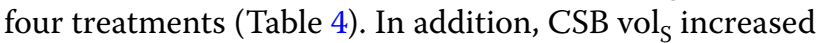



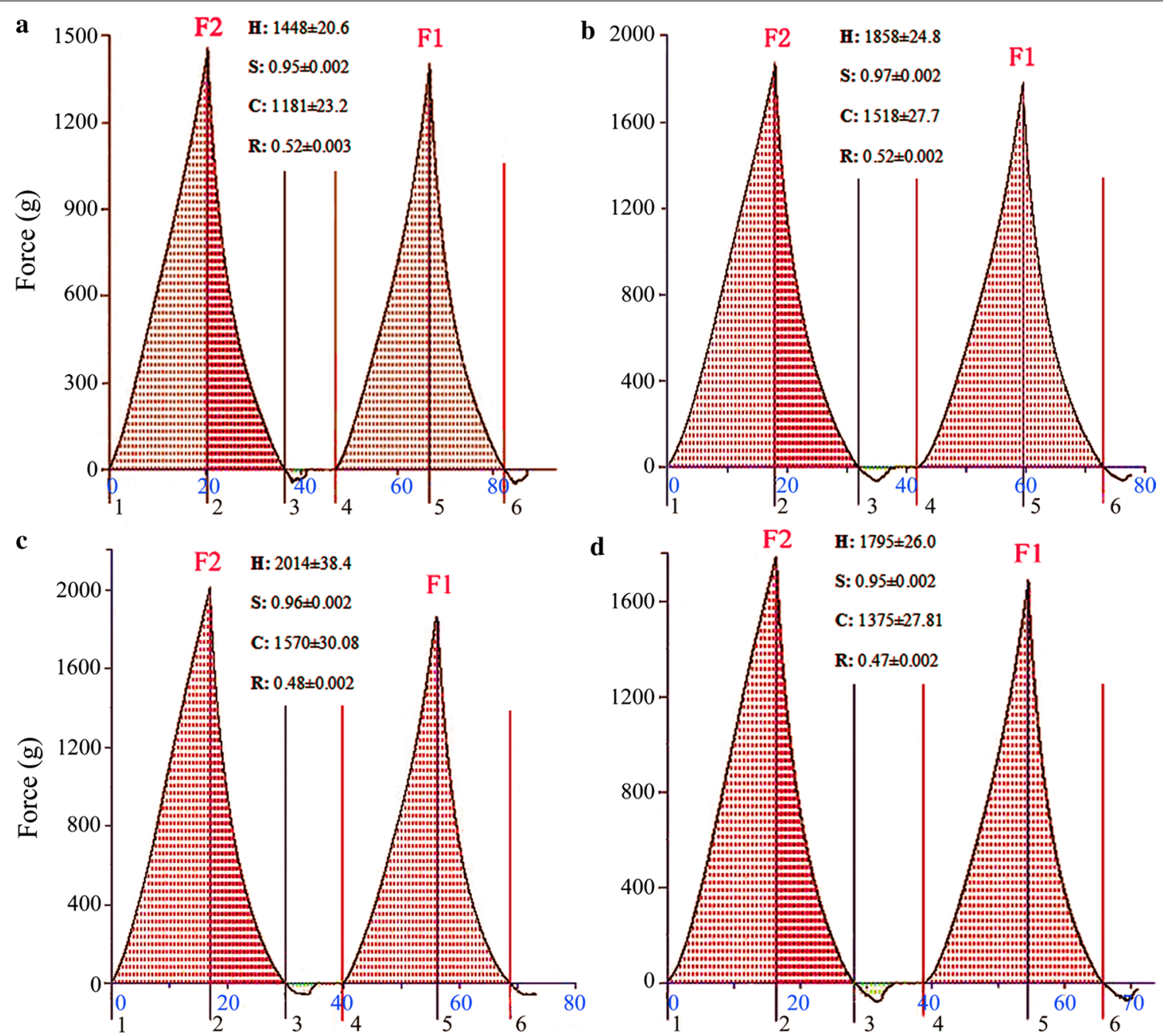

Time (second)

Time (second)

Fig. 6 Texture profile analysis of CSBs treated by $\mathrm{FB}_{\mathrm{G}}$. a The reference; $\mathbf{b} 0.025 \mathrm{ml} / \mathrm{g} ; \mathbf{c} 0.05 \mathrm{ml} / \mathrm{g} ; \mathbf{d} 0.10 \mathrm{ml} / \mathrm{g}$. Interpretation of texture parameters: Hardness $=$ F2; Springiness $=$ time $_{4-5} /$ time $_{1-2} ;$ Chewiness $=F 2 \times\left(\right.$ area $_{4-6} /$ area $\left._{1-3}\right) \times\left(\right.$ time $_{4-5} /$ time $\left._{1-2}\right) ;$ Resilience $=$ area $_{2-3} /$ area $_{1-2}$

with improvement of the total pore area, but the hardness and chewiness decreased with it. These results were in accordance with the description of Fig. 3. Thus, the addition of glucose and maltose can enlarge $\operatorname{vol}_{S}$ and reduce hardness and chewiness of CSB. The reason is that S. cerevisiae was added to flour during CSB making, and both glucose and maltose are carbon resources for the growth of $S$. cerevisiae. The appearance of glucose and maltose in flour makes the yeast produce more $\mathrm{CO}_{2}$ during the fermentation phase, resulting in the appearance of the larger pore area in crumb. The larger pore area, on one hand, leads to enlargement of CSB volume; on the other hand, it decreases hardness and chewiness since the gas in CSB is easy compressed. Similar results have been reported in the literature that addition of a-amylase can increase CSB
$\mathrm{vol}_{\mathrm{S}}$ by increasing gas production at the fermentation stage (Sanz Penella et al. 2008).

Now, we can deduce why hardness and chewiness of CSB decreased at the $\mathrm{FB}_{\mathrm{G}}$ dosage of $0.10 \mathrm{ml} / \mathrm{g}$. Hardness and chewiness of CSB are determined by three factors i.e. protein cross-linkage, Ae/An ratio and CSB volume. Both protein cross-linkage and rise of Ae/An ratio result in the increase of hardness and chewiness, but, the larger $\operatorname{vol}_{S}$ decreases them. When $0.025-0.05 \mathrm{ml} / \mathrm{g}$ of $\mathrm{FB}_{\mathrm{G}}$ was added to flour, the increments of hardness and chewiness from protein cross-linkage and Ae/An ratio change are more than the decrements. As a whole, hardness and chewiness of CSB are increased. When the $\mathrm{FB}_{\mathrm{G}}$ dosage reaches $0.10 \mathrm{ml} / \mathrm{g}$, the higher amylase activity catalyzes starch to produce more glucose and maltose, which results in the 


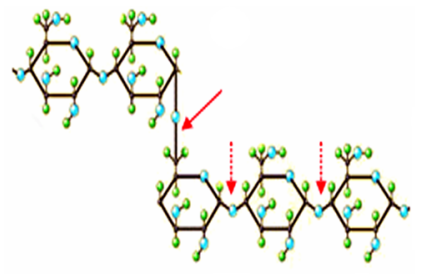

Amylopectin

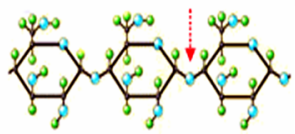

Amylose
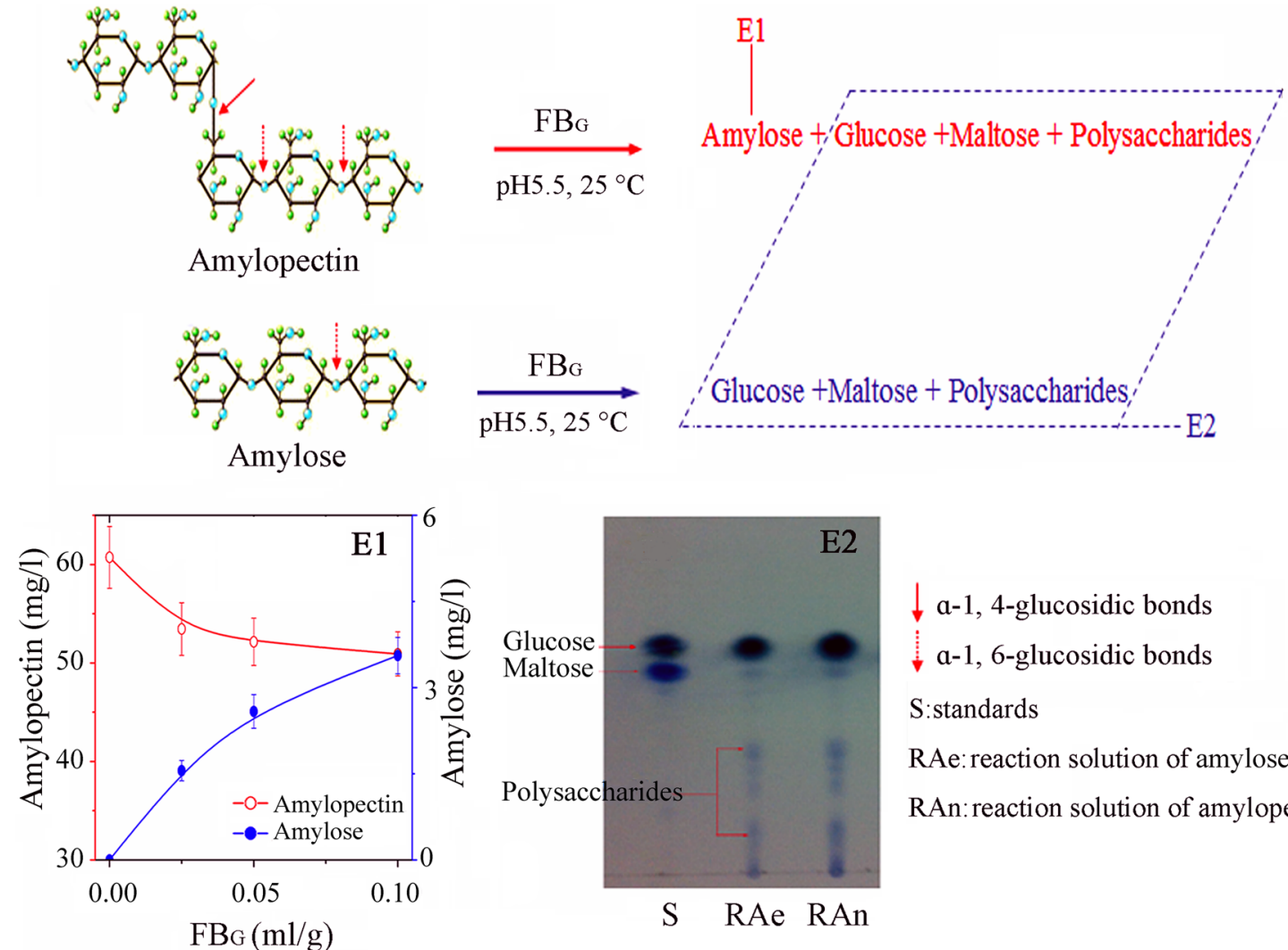

$\downarrow$ a-1, 4-glucosidic bonds

a-1, 6-glucosidic bonds

S:standards

RAe: reaction solution of amylose

RAn: reaction solution of amylopectin

Fig. 7 Reactions and evidences of starch degradation catalyzed by FB $\mathrm{G}_{\mathrm{G}}$ E1, The concentrations of amylopectin and amylose after $3 \mathrm{~h}$ reaction; $\mathrm{E}_{2}$, TLC analysis of the products of amylopectin and amylose treated by $F B_{G}$

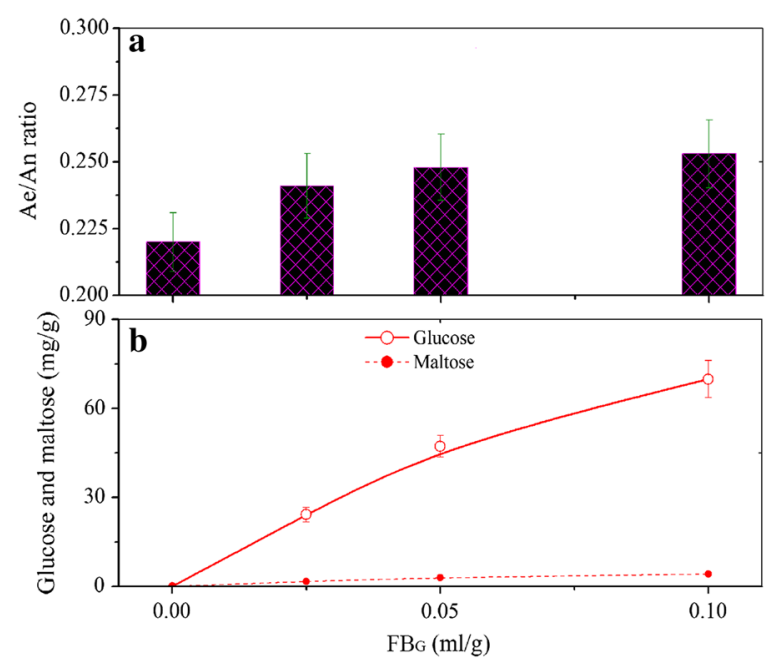

Fig. 8 Variations of Ae/An ratio as well as glucose and maltose content with the $\mathrm{FB}_{\mathrm{G}}$ dosage. a Variation of $\mathrm{Ae} / \mathrm{An}$ ratio; $\mathbf{b}$ variations of glucose and maltase content enlargement of $\mathrm{vol}_{\mathrm{S}}$, and decrements of hardness and chewiness are more than their increments. Thus, hardness and chewiness of CSB are decreased.

In this work, $\mathrm{FB}_{\mathrm{G}}$ was added to flour as a food additive and the mechanism of $\mathrm{FB}_{\mathrm{G}}$ impacting on CSB properties was revealed. The $\mathrm{FB}_{\mathrm{G}}$ is directly obtained from submerged cultivation, and thus its cost is cheaper than those of the purified enzymes (Victoria et al. 2013; Selinheimo et al. 2006,2007; Su et al. 2005; Shah et al. 2006). Moreover, $\mathrm{FB}_{\mathrm{G}}$ containing laccase and amylases improves CSB quality significantly, the same as the purified enzymes do. It catalyzes the cross-linkage of proteins, conversion of amylopectin to amylose and degradation of starch, resulting in the changes of CSB properties including $\mathrm{vol}_{S}$, crumb's micro-structure, recovery after compression, stickiness and so forth. The finding presented herein not only is helpful to further understand the functions of $\mathrm{FB}_{\mathrm{G}}$ in improving CSB quality from the perspectives of protein crosslinkage and starch degradation, but also is valuable 
Table 3 Effect of Ae/An ratio on the hardness and chewiness of CSB

\begin{tabular}{lllllll}
\hline Flour & Starch (\%) & Ae (\%) & An (\%) & Ae/An & Hardness (g) & Chewiness (g) \\
\hline 1 & 67.5 & 13.1 & 54.4 & 0.241 & 1630 & 1410 \\
2 & 70.0 & 12.8 & 57.2 & 0.224 & 1460 & 1210 \\
3 & 70.4 & 15.1 & 55.3 & 0.273 & 2810 & 1910 \\
4 & 69.1 & 14.5 & 58.5 & 0.248 & 1980 & 1620 \\
5 & 65.5 & 13.4 & 52.1 & 0.257 & 2210 & 1830 \\
6 & 71.3 & 14.4 & 56.9 & 0.253 & 2150 & 1740 \\
\hline
\end{tabular}

An: Amylopectin; Ae: amylose

Table 4 Effect of glucose and maltose on the properties of CSB

\begin{tabular}{llllllll}
\hline Treatment & Glucose $\mathbf{( m g / g )}$ & $\begin{array}{l}\text { Maltose } \\
(\mathbf{m g} / \mathbf{g})\end{array}$ & Pore number & Pore area $\left.\mathbf{( m m}^{\mathbf{2}}\right)$ & Specific volume & Hardness $(\mathbf{k g})$ & Chewiness $(\mathbf{k g})$ \\
\hline 1 & 0 & 0 & 1242 & 346.8 & 17.4 & 1600 & 1212 \\
2 & 24.2 & 1.7 & 1566 & 364.7 & 18.3 & 1460 & 1150 \\
3 & 47.4 & 3.0 & 1332 & 382.9 & 19.2 & 1368 & 1095 \\
4 & 69.9 & 4.1 & 1282 & 416.2 & 19.7 & 1274 & 1007 \\
\hline
\end{tabular}

for CSB industry because it will quite likely present a relative cheap food additive. In the future investigation, except protein and starch, the effect of $\mathrm{FB}_{\mathrm{G}}$ on the other components of flour also deserves to be studied. Moreover, the dosage of $\mathrm{FB}_{\mathrm{G}}$ should be further studied before the extensive applications in food industry can be considered.

\section{Acknowledgements}

The authors are thankful to the technical support from Advanced Environmental Biotechnology Center, Nanyang Technological University, Singapore.

\section{Authors' contributions}

Planning and designing of study: WH; Experimentation: ZG and LY; Data analysis and manuscript drafting: WL. All authors read and approved the final manuscript.

\section{Funding}

This work was supported by the National Science Foundation of China (U16041 1067), and Plan for Scientific Innovation Talent of Henan Province (18HASTIT039).

\section{Availability of data and materials \\ Not applicable}

\section{Ethics approval and consent to participate}

The study was conducted according to the Declaration of Helsinki and approved by Medical Ethical Committee of the Henan Normal University. Informed consent was obtained from all human participates.

\section{Consent for publication}

All authors including Zhao Guowei, Wei Lili, Liu Yufeng and Wang Hailei agree to submit the work to AMB Express.

\section{Competing interests}

The authors declare that they have no competing interests.
Author details

${ }^{1}$ College of Life Sciences, Henan Normal University, Xinxiang 453007, China.

2 Department of Life Science and Engineering, Jining College, Qufu 273155,

China.

Received: 6 June 2019 Accepted: 17 Auqust 2019

Published online: 27 August 2019

\section{References}

Adejumo AL, Aderibigbe FA, Owolabi RU (2013) Relationship between a-amylase degradation and amylose/amylopectin content of maize starches. Adv Appl Sci Res 4:315-319

Ercili CD, Lantto R, Lille M, Andberg M, Kruus K, Buchert J (2009) Laccase-aided protein modification: effects on the structural properties of acidified sodium caseinate gels. Int Dairy J 19:737-745. https://doi.org/10.1016/j. idairyj.2009.06.007

Figueroa-Espinoza MC, Rouau X (1998) Oxidative cross-linking of pentosans by a fungal laccase and horseradish peroxidase: mechanism of linkage between feruloylated arabinoxylans. Cereal Chem 75:259-265. https:// doi.org/10.1094/CCHEM.1998.75.2.259

Figueroa-Espinoza MC, Morel MH, Surget A, Asther M, Moukha S, Sigoillot JC, Rouau X (1999) Attempt to cross-link feruloylated arabinoxylans and proteins with a fungal laccase. Food Hydrocoll 13:65-71. https://doi. org/10.1016/S0268-005X(98)00072-1

Flander L, Rouau X, Morel MH, Autio K, Seppänen-Laakso T, Kruus K, Buchert $J$ (2008) Effects of laccase and xylanase on the chemical and rheological properties of oat and wheat doughs. J Agr Food Chem 56:5732-5742. https://doi.org/10.1021/jf800264a

Flander L, Holopainen U, Kruus K (2011) Effects of tyrosinase and laccase on oat proteins and quality parameters of gluten-free oat breads. J Agr Food Chem 59:8385-8390. https://doi.org/10.1021/jf200872r

Gao LY, Ma WJ, Chen J, Wang K, Li J, Wang SL, Bekes F, Appels R, Yan YM (2010) Characterization and comparative analysis of wheat high molecular weight glutenin subunits by SDS-PAGE, RP-HPLC, HPCE, and MALDI-TOFMS. J Agr Food Chem 58:2777-2786. https://doi.org/10.1021/jf903363z

Kadan RS, Robinson MG, Thibodeaux DP, Pepperman JAB (2001) Texture and other physicochemical properties of whole rice bread. J Food Sci 66:940-944. https://doi.org/10.1111/j.1365-2621.2001.tb08216.x 
Ko EM, Leem YE, Choi H (2001) Purification and characterization of laccase isozymes from the white-rot basidiomycete Ganoderma lucidum. App Microbiol Biotechnol 57:98-102. https://doi.org/10.1007/s002530100727

Kudanga T, Nyanhongo GS, Guebitz GM, Burton S (2011) Potential applications of laccase-mediated coupling and grafting reactions: a review. Enzyme Microb Technol 48:195-208. https://doi.org/10.1016/j.enzmi ctec.2010.11.007

Labat E, Morel MH, Rouau X (2000) Effect of laccase and ferulic acid on wheat flour doughs. Cereal Chem 77:823-828. https://doi.org/10.1094/CCHEM 2000.77.6.823

Li P, Wang HL, Liu GS, Li X, Yao JM (2011) The effect of carbon source succession on laccase activity in the co-culture process of Ganoderma lucidum and a yeast. Enzyme Microb Technol 48:1-6. https://doi.org/10.1016/j. enzmictec.2010.07.005

Lin Q, Liu LN, Bi Y, Li ZG (2012) Effects of different debranning degrees on the qualities of wheat flour and Chinese steamed bread. Food Bioproc Tech 5:648-656. https://doi.org/10.1007/s11947-010-0335-3

Liu YD, Ying YB, Yu HY, Fu XP (2006) Comparison of the HPLC method and FBNIR analysis for quantification of glucose, fructose, and sucrose in intact apple fruits. J Agr Food Chem 54:2810-2815. https://doi.org/10.1021/ jf052889e

Minussi RC, Pastore GM, Duran N (2002) Potential applications of laccase in the food industry. Trends Food Sci Technol 13:205-216. https://doi. org/10.1016/S0924-2244(02)00155-3

Nakamura Y (2002) Towards a better understanding of the metabolic system for amylopectin biosynthesis in plants: rice endosperm as a model tissue. Plant Cell Physiol 43:718-725. https://doi.org/10.1093/pcp/pcf091

Oliveira DS, Telis-Romero J, Da-Silva R, Franco CML (2014) Effect of a Thermoascus aurantiacus thermostable enzyme cocktail on wheat bread quality. Food Chem 143:139-146. https://doi.org/10.1016/j.foodc hem.2013.07.103

Pyler EJ (1988) Baking science and technology, 3rd edn. Sosland Pub Co., Kansas

Sanz Penella JM, Collar C, Haros M (2008) Effect of wheat bran and enzyme addition on dough functional performance and phytic acid levels in bread. J Cereal Sci 48:715-721. https://doi.org/10.1016/j.jcs.2008.03.006

Sapirstein HD, Roller R, Bushuk W (1994) Instrumental measurement of bread crumb grain by digital image analysis. Cereal Chem 71:383-391. https:// doi.org/10.1021/bp00028a015

Selinheimo E, Kruus K, Buchert J, Hopia A, Autio K (2006) Effects of laccase, xylanase and their combination on the rheological properties of wheat doughs. J Cereal Sci 43:152-159. https://doi.org/10.1016/j.jcs.2005.08.007

Selinheimo E, Autio K, Kruus K (2007) Elucidating the mechanism of laccase and tyrosinase in wheat bread making. J Agr Food Chem 55:6357-6365. https://doi.org/10.1021/jf0703349

Shah AR, Shah RK, Madamwar D (2006) Improvement of the quality of whole wheat bread by supplementation of xylanase from Aspergillus foetidus. Bioresour Technol 97:2047-2053. https://doi.org/10.1016/j.biort ech.2005.10.006

Singh J, Dartois A, Kaur L (2010) Starch digestibility in food matrix: a review. Trends Food Sci Technol 21:168-180. https://doi.org/10.1016/j. tifs.2009.12.001
Stanley G, Harvey K, Slivova V, Jiang JH, Sliva D (2005) Ganoderma lucidum suppresses angiogenesis through the inhibition of secretion of VEGF and TGF- $\beta 1$ from prostate cancer cells. Biochem Biophys Res Commun 330:46-52. https://doi.org/10.1016/j.bbrc.2005.02.116

Su DM, Ding CH, Li L, Su D, Zheng XY (2005) Effect of endoxylanases on dough properties and making performance of Chinese steamed bread. Eur Food Res Technol 220:540-545. https://doi.org/10.1007/s00217-005-1170-z

Victoria KA, Gao J, Zhou WB (2013) Impact of green tea extract and fungal alpha-amylase on dough proofing and steaming. Food Bioproc Tech 6:3400-3411. https://doi.org/10.1007/s11947-012-0986-3

Wang HL, Tang CZ, Yu GL, Li P (2013) A novel membrane-surface liquid coculture to improve the production of laccase from Ganoderma lucidum. Biochem Eng J 80:27-36. https://doi.org/10.1016/j.bej.2013.09.003

Wu C, Liu RS, Huang WN, Rayas-Duarte P, Wang F, Yao Y (2012) Effect of sourdough fermentation on the quality of Chinese northern-style steamed breads. J Cereal Sci 56:127-133. https://doi.org/10.1016/j.jcs.2012.03.007

Xu JW, Xu YN, Zhong JJ (2010) Production of individual ganoderic acids and expression of biosynthetic genes in liquid static and shaking cultures of Ganoderma lucidum. Appl Microbiol Biotechnol 85:941-948. https://doi. org/10.1007/s00253-009-2106-5

Zghal MC, Scanlon MG, Sapirstein HD (2001) Effects of flour strength, baking absorption, and processing conditions on the structure and mechanical properties of bread crumb. Cereal Chem 78:1-7. https://doi.org/10.1094/ CCHEM.2001.78.1.1

Zhou HB, Bi PY, Wu XT, Huang FR, Yang HL (2014) Improved polysaccharide production in submerged culture of Ganoderma lucidum by the addition of Coixenolide. Appl Biochem Biotechnol 172:1497-1505. https://doi. org/10.1007/s12010-013-0623-2

Zhu F, Bertoft E, Seetharaman K (2013) Characterization of internal structure of maize starch without amylose and amylopectin separation. Carbohyd Polym 93:116-121. https://doi.org/10.1016/j.carbpol.2013.04.092

Zilly A, Bazanella GCS, Helm CV, Araújo CAV, Souza CGM, Bracht A, Peralta RM (2012) Solid-state bioconversion of passion fruit waste by white-rot fungi for production of oxidative and hydrolytic enzymes. Food Bioproc Tech 5:1573-1580. https://doi.org/10.1007/s11947-011-0532-8

Zou W, Yu L, Liu XX, Chen L, Zhang XQ, Qiao DL, Zhang RZ (2012) Effects of amylose/amylopectin ratio on starch-based superabsorbent polymers. Carbohyd Polym 87:1583-1588. https://doi.org/10.1016/j.carbp ol.2011.09.060

\section{Publisher's Note}

Springer Nature remains neutral with regard to jurisdictional claims in published maps and institutional affiliations.

\section{Submit your manuscript to a SpringerOpen ${ }^{\circ}$ journal and benefit from:}

- Convenient online submission

- Rigorous peer review

- Open access: articles freely available online

- High visibility within the field

Retaining the copyright to your article

Submit your next manuscript at springeropen.com 